\title{
Resistance of modified polyvinyl chloride/wood flour composites to basidiomycetes
}

\author{
Marcus Müller • Antje Gellerich • Holger Militz • \\ Andreas Krause
}

Received: 28 November 2011/Published online: 10 February 2013

(c) The Author(s) 2013. This article is published with open access at Springerlink.com

\begin{abstract}
Aminosilane, melamine and acetic anhydride treated wood flour were added to polyvinyl chloride (PVC) and manufactured into wood-plastic composites (WPC) panels in order to investigate the influence of modification on the resistance to basidiomycetes of the composite. The composite consisted of $50 \mathrm{wt} \%$ wood and $50 \mathrm{wt} \%$ PVC dry blend. White rot (Trametes versicolor) and brown rot (Coniophora puteana) fungi were used to inoculate the composite. Test procedure was carried out according to ENV 12038 with an additional water pre-treatment of the composite. All tested formulations showed high resistance to basidiomycetes under the test conditions. With regard to the modifications used, only aminosilane treated composites showed slightly decreased weight loss values compared to the untreated reference.
\end{abstract}

\section{Resistenz von modifizierten Holz-Kunststoff Komposi- ten gegenüber Basidiomyceten}

Zusammenfassung Für die Modifizierung der Holzkomponente wurden verschiedene Aminosilane, Melamin und Essigsäureanhydrid verwendet. Das behandelte Holzmehl wurde mit PVC zu WPC-Platten verarbeitet, um den Einfluss der Holzmodifizierung auf die Dauerhaftigkeit des Komposits zu untersuchen. Das Mischungsverhältnis von Holz zu PVC dry blend betrug 50/50 Gewichtsprozent. Weiß- und Braunfäulepilze (Trametes versicolor, Coniophora puteana) wurden mit dem Testmaterial beimpft. Die Resistenzprüfung wurde in Anlehnung an ENV 12038 durchgeführt, wobei

M. Müller · A. Gellerich · H. Militz · A. Krause ( $\square)$ Department of Wood Biology and Wood Products, University of Göttingen, Büsgenweg 4,

37077 Göttingen, Germany

e-mail: akrause2@gwdg.de eine zusätzliche Wasserlagerung der Komposite vor Versuchsbeginn implementiert wurde. Alle Formulierungen zeigten eine hohe Resistenz gegenüber Basidiomyceten. Im Vergleich zur unbehandelten Referenz wurden lediglich bei den Aminosilan behandelten Kompositen leicht verringerte Masseverluste gemessen.

\section{Introduction}

Wood-plastic composites (WPC) have gained a rapid worldwide market share in the last decades. This new hybrid material is used in exterior building applications such as deckings, railings and sidings (Clemons 2002; Wolcott and Englund 1999; Vogt et al. 2005). Mainly polyolefins (polyethylene, polypropylene) are used as polymer matrix for WPC, so that most of the scientific studies are dealing with the property analysis of these composites. Since polyvinylchloride showed improved weatherability, stiffness, creep behavior and flame retardancy compared to previously mentioned polymers, it became more important for the use in WPC (Jiang and Kamdem 2004).

Still, the compatibility of wood and polymer is limited. The poor interfacial adhesion between the hydrophilic wood surface and the hydrophobic polymer leads to weak mechanical properties (Kokta et al. 1990a, b). In addition the moisture uptake is accelerated, caused by internal gaps and voids of the material. The attendance of moisture in a wood based composite increases the risk of fungal decay. While mold and blue stain affect discolorations of the composite, basidiomycetes such as white and brown rot fungi cause decomposition of the wood and therefore reduced mechanical properties of the composite (DawsonAndoh et al. 2004; Schirp et al. 2008). Parameters that 
influence the biological durability of WPC are wood content, manufacturing method of the composite and wood species used. In addition there are various test methods (e.g., ENV 12038, ASTM D 2017-05) to determine the weight loss of the material (Silva et al. 2007; Lopez et al. 2005). With increasing wood content, the durability is reduced, due to the fact that neat polymer is not degraded by the fungi (Verhey et al. 2001). Concerning the manufacturing method, it is reported that injection molded samples exhibit the lowest weight loss compared to hot pressed and extruded ones (Clemons and Ibach 2004). In general it is said that wood species with higher durability are also causing higher durability of the composite (Stokke and Gardner 2003; Fabiyi et al. 2011; Kim et al. 2008). In contrast to solid wood, water uptake, water diffusion and water release is obviously reduced in WPC (Steckel et al. 2007; Chen et al. 2006). Thus, water pre-treatment of the samples is necessary to obtain suitable moisture contents for fungal decay and to create worst condition for the composite (Defoirdt et al. 2010; Rowell 2007; Kim et al. 2008, 2009).

In order to reduce the moisture uptake of the wooden component, various modifications are possible. The hydrophilic nature of wood is due to the presence of free hydroxyl groups in all cell wall layers and chemical components. Blocking and/or minimizing these hydroxyl groups is the main goal of wood modification. Reduced water uptake of WPC can be achieved by using methylated melamine-formaldehyde resin (Müller et al. 2012). After the curing process, the thermoset remains in the cell wall. It is reported that treatments with melamine formaldehyde resin improve dimensional stability and biological durability of solid wood (Lukowsky 1999; Rapp and Peek 1996; Rapp et al. 1999; Inoue et al. 1993; Gindl et al. 2003). The second treatment used in this study is the acetylation of the wood with acetic anhydride. Acetylation causes a reaction of acetic anhydride with the hydroxyl groups of wood forming acetyl-groups and acetic acid. Several studies reveal positive effects on durability and dimensional stability properties (Brelid et al. 2000; Takahashi et al. 1989; Beckers et al. 1994; Rowell et al. 1989). In addition two different aminosilanes were used to modify the wood. In contrast to the previously mentioned modifications, aminosilanes are acting as coupling agents between wood and PVC, so that besides a hydrophobic treatment, the interphase is improved (Müller et al. 2012; Matuana et al. 1998a,b; Sombatsompop and Chaochanchaikul 2005; Kokta et al. 1990b). The majority of scientific papers focus on investigations concerning the durability of PP and PE based WPC. The aim of this study is to investigate the resistance of PVC based WPC to brown and white rot fungi. Furthermore the influence of various wood modifications on the durability of the composite is examined.

\section{Experimental}

\subsection{Material}

Polyvinyl chloride (263 RB) with a K-value of 63 was provided by Solvin SA in the form of powder. Wood flour particles (C 100) were obtained from wood milling processes and supplied by JRS GmbH + Co.KG. The average size of the wood flour particles (Picea abies) was in the range of $50-150 \mu \mathrm{m}$. The following modification agents were used: $\gamma$-aminopropyltriethoxysilane (Ameo) has monomeric structure; Dynasylan HS 2909 is derived from complete hydrolysis and partial condensation of monomeric ethoxysilanes, containing amino -as well as hydroxyl groups which can be subject to further condensation. Aminosilanes were provided by Evonik AG, Essen. Furthermore, methylated melamine-formaldehyde resin was applied (Madurit MW840, Ineos melamines $\mathrm{GmbH}$ ) with a solid content of $75 \%$ solved in water. For acetylation process acetic anhydride (provided by Th. Geyer GmbH \& Co. KG) was used in this study. To complete the formulation, following additives were mixed with main components: $\mathrm{Ca} / \mathrm{Zn}$ stabilizer (Mark CZ 2000, Chemtura), polyethylene based wax (Loxiol G60, Clariant $\mathrm{GmbH}$ ) glycerin stearate (Ligalub GT, Peter Greven Fettchemie $\mathrm{GmbH}$ ) and aliphatic acid (Loxiol G20, Clariant $\mathrm{GmbH}$ ) as lubricants and calcium carbonate (Omyate 95T, Omya $\mathrm{GmbH}$ ) as mineral filler.

\subsection{Methods}

\subsubsection{Wood flour treatment}

Aminosilanes and melamine resin were solved in water and applied to wood flour in concentrations of 1 and $10 \mathrm{wt} \%$ (abbreviations: 1Ameo, 10Ameo, 1HS2909, 10HS2909, $1 \mathrm{Mel}, 10 \mathrm{Mel})$. Acetylation was performed using a $40 \%$ acetic anhydride in a solution with ethanol (abbreviation: Acetyl). Solutions were sprayed onto oven dried (48 h at $103{ }^{\circ} \mathrm{C}$ ) wood flour in a mixing drum. Afterwards treated wood flour was first dried in a vacuum heated chamber to a moisture content below $1 \%$. Subsequently the temperature was raised to $120{ }^{\circ} \mathrm{C}$ to obtain suitable reaction conditions. In addition untreated wood flour was used as reference (abbreviation: Ref). Ref was treated with water in the same way to reduce the impact of the treatment process itself, e.g., particle destruction, on the results.

\subsubsection{Processing of PVC wood flour composites}

Treated and untreated wood flour, PVC and additives were dry blended in a mixer (Reimelt Henschel, FM L $30 \mathrm{KM}$ 85) until a product temperature of $120{ }^{\circ} \mathrm{C}$ was reached. 
Table 1 Weight percentage of composite ingredients

Tab. 1 Prozentualer Anteil der Formulierungsbestandteile basierend auf dem Gewicht

\begin{tabular}{lc}
\hline Ingredient & wt $\%$ \\
\hline Suspension PVC & 43.84 \\
Ca/Zn stabilizer & 1.1 \\
Polyethylene wax & 0.07 \\
Glycerin stearate & 0.52 \\
Aliphatic acid & 0.09 \\
Calcium carbonate & 4.38 \\
Wood flour (dried) & 50 \\
\hline
\end{tabular}

Composition details are listed in Table 1. Dry blend was compounded to granulate by counter-rotating twin screw extrusion (Leistritz MICRO 27). Compounding parameters were adjusted to obtain an average mass temperature of $180{ }^{\circ} \mathrm{C}$ at a screw rotating speed of $65 \mathrm{rpm}$. The composites were compression molded into panels $(4 \times 280 \times$ $340 \mathrm{~mm}^{3}$ ) using a hydraulic press (Joos, HP-S 200LAB) at $190{ }^{\circ} \mathrm{C}$ and 60 bar for $5 \mathrm{~min}$. To avoid lateral expansion of the polymer, a pressing frame was used. Temperature was slowly reduced via water cooling $(20 \mathrm{~min})$ to allow compressed hardening of the composite. In addition one formulation was processed without wood flour to compare the influence of fungal decay on the neat PVC (abbreviation: PVC).

\subsubsection{Water pre-treatment}

Pre-treatment with water was implemented before the WPC and PVC samples were inoculated by fungi. Moisture uptake of the composites was measured according to EN 62 . Eight replicates $\left(50 \times 50 \times 4 \mathrm{~mm}^{3}\right)$ for each formulation were selected and oven dried for $48 \mathrm{~h}$ at $103{ }^{\circ} \mathrm{C}$. The dried samples were weighed to a precision of $0.01 \mathrm{~g}$ and subsequently placed in distilled water. Water uptake was calculated after $672 \mathrm{~h}$ using Eq. 1.

$M C_{1}(\%)=\frac{M_{672 h}-M_{1}}{M_{1}} \times 100$

where moisture content $\mathrm{MC}_{1}(\%)$ is described by mass[g] of dried (M1) and submersed $\left(\mathrm{M}_{672 \mathrm{~h}}\right)$ sample.

\subsubsection{Sample preparation and fungal inoculation}

Method for determining the resistance against wood destroying basidiomycetes was carried out according to ENV 12038. Solid wood size control samples (Pinus sylvestris, Picea abies and Fagus sylvatica) had the same shape as the PVC and WPC-specimens $(50 \times 50 \times$ $4 \mathrm{~mm}^{3}$ ). The virulence control samples (Pinus sylvestris for brown rot fungi and Fagus sylvatica for white rot fungi) were in the dimensions of $50 \times 25 \times 15 \mathrm{~mm}^{3}$. Both, size control samples and virulence control samples were oven dried $\left(48 \mathrm{~h}, 103^{\circ} \mathrm{C}\right)$ and then conditioned to a moisture content of $12 \%( \pm 2)$ in a climate chamber. The used test fungi were Coniophora puteana $(C p)$ as a brown rot and Trametes versicolor $(T v)$ as white rot fungus. The mycelia of the fungi were inoculated into the test vessels (petri dishes) with malt extract agar medium on the ground and placed in a climate chamber $\left(7\right.$ days at $22{ }^{\circ} \mathrm{C} / 70 \%$ relative humidity). Before the samples were placed into the inoculated vessels, they were sterilized twice within $24 \mathrm{~h}$ by hot steam in an autoclave for $20 \mathrm{~min}$ at $121{ }^{\circ} \mathrm{C}$. There was no spacer used between the samples and the fungal mycelia. For each formulation (PVC, WPC, size control samples and virulence control samples) eight replicates were used to determine the weight loss. Each sample was placed in a separated vessel and exposed to fungal attack for 16 weeks. The samples were oven dried after the end of the test to calculate the moisture content and the weight loss using Eqs. 2 and 3, respectively. The moisture contents and weight losses of the WPC samples are calculated by measuring the mass of the whole composite.

$M C_{2}(\%)=\frac{M_{2}-M_{3}}{M_{3}} \times 100$

where moisture content $\mathrm{MC}_{2}(\%)$ is described by mass $(\mathrm{g})$ of undried $\left(\mathrm{M}_{2}\right)$ and dried $\left(\mathrm{M}_{3}\right)$ sample after the end of the test.

$W L(\%)=\frac{M_{1}-M_{3}}{M_{1}} \times 100$

where weight loss $(\%)$ is described by mass $(\mathrm{g})$ of dried sample before $\left(M_{1}\right)$ and after the end of the test $\left(M_{3}\right)$.

\section{Results and discussion}

\subsection{Moisture content}

The moisture contents $\left(\mathrm{MC}_{1}\right.$ and $\left.\mathrm{MC}_{2}\right)$ of treated and untreated WPC and neat PVC are presented in Fig. 1. Since gaps and voids between wood and polymer cause an additional possibility of moisture occurrence within the material, the moisture content was calculated for the whole WPC samples. Reduced moisture content was observed after the water-pretreatment for modified PVC/wood flour composites, with the exception of low concentrated Ameo (1Ameo) treatment. The lowest water uptake was measured for $10 \mathrm{HS} 2909$ and $10 \mathrm{Mel}$, which suggests that the treatment with the mentioned chemicals was successful (Müller et al. 2012; Lukowsky 1999; Donath 2004). After 16 weeks of fungi inoculation, the moisture content of the composites increased obviously. The results are comparable with further studies and indicate that the maximum water 
Fig. 1 Moisture content of treated and untreated WPC and neat PVC before inoculation (MC1) and after fungal attack (MC2)

Abb. 1 Materialfeuchte des behandelten und unbehandelten WPC und der PVC-

Grundmischung vor Einbau (MC1) und nach Versuchsende (MC2)

Fig. 2 Weight loss of size control samples

Abb. 2 Masseverlust der MessKontrollproben
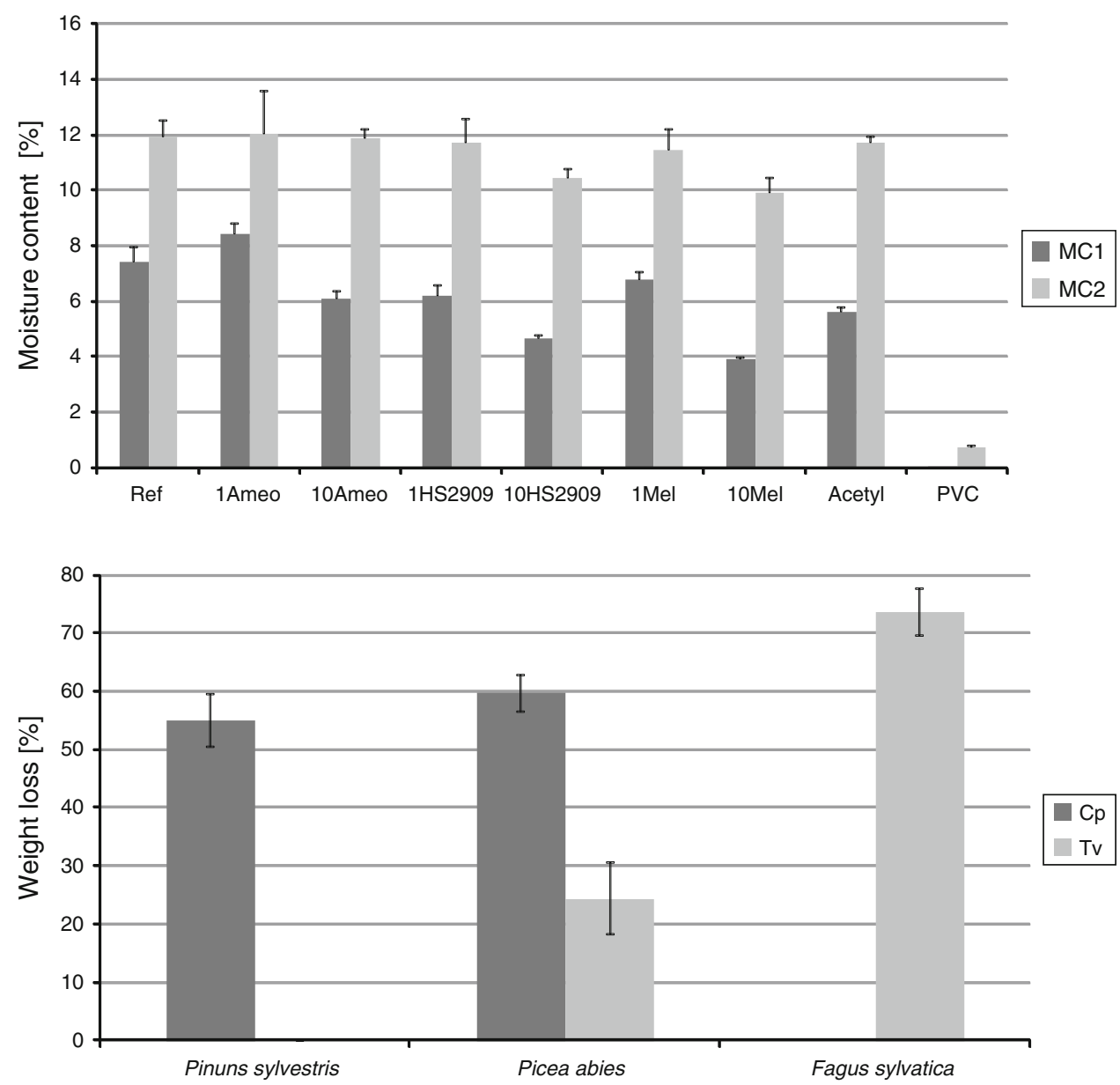

absorption of treated and untreated WPC was reached (Müller et al. 2012).

\subsection{Weight loss}

The weight loss evaluation of the virulence control samples showed that the test was valid. According to the standard, an average weight loss of $20 \%$ had to be reached. Pinus sylvestris virulence control samples showed an average weight loss of $38 \%$ and Fagus sylvatica virulence control samples of $24 \%$ (data not shown), respectively. The weight losses of the size control samples are illustrated in Fig. 2. In general the dimensions of the size control samples cause higher weight losses compared to the virulence control samples. This could be explained with a higher surface/volume ratio of the size control samples and therefore a better accessibility to the fungi. Picea abies were used to compare the weight loss of solid wood size control samples with the WPC ones. As expected the weight loss of brown rot were twice as high as that of white rot (Reinprecht et al. 2007).

Figure 3 illustrates the weight losses of treated and untreated WPC and neat PVC. The weight losses of the composites were calculated for the whole sample, since the neat PVC samples showed slight degradation. Polymer degradation was observed in previous studies using plasticized PVC/cellulose composites (Kaczmarek and Bajer 2007). According to the used standard, the results indicate that the investigated composites are highly resistant to basidiomycetes. There are various reasons that cause the measured weight losses. The moisture contents of the composites were below the limit of fungal activity after inoculation (Kaczmarek and Bajer 2007). Even after the end of the test, the moisture contents were at a critical level for fungal decay. Though a water pre-treatment of $672 \mathrm{~h}$ was implemented, it was not possible to reach suitable moisture contents for fungal decay. In further studies water boiling tests were used to pre-treat the samples and accelerate the ageing procedure. However, reduced mechanical properties were measured, suggesting more gaps and voids in water boiled samples and a worse interphase than in water soaked ones (Schirp et al. 2008). Still more investigations are needed to analyze the influence of water boiling on the structure changes of WPC.

With regard to the reduced water uptake and fungal decay, the wood content of the composite has to be 
Fig. 3 Weight loss of treated and untreated WPC and neat PVC

Abb. 3 Masseverlust des behandelten und unbehandelten WPC und der PVC-

Grundmischung

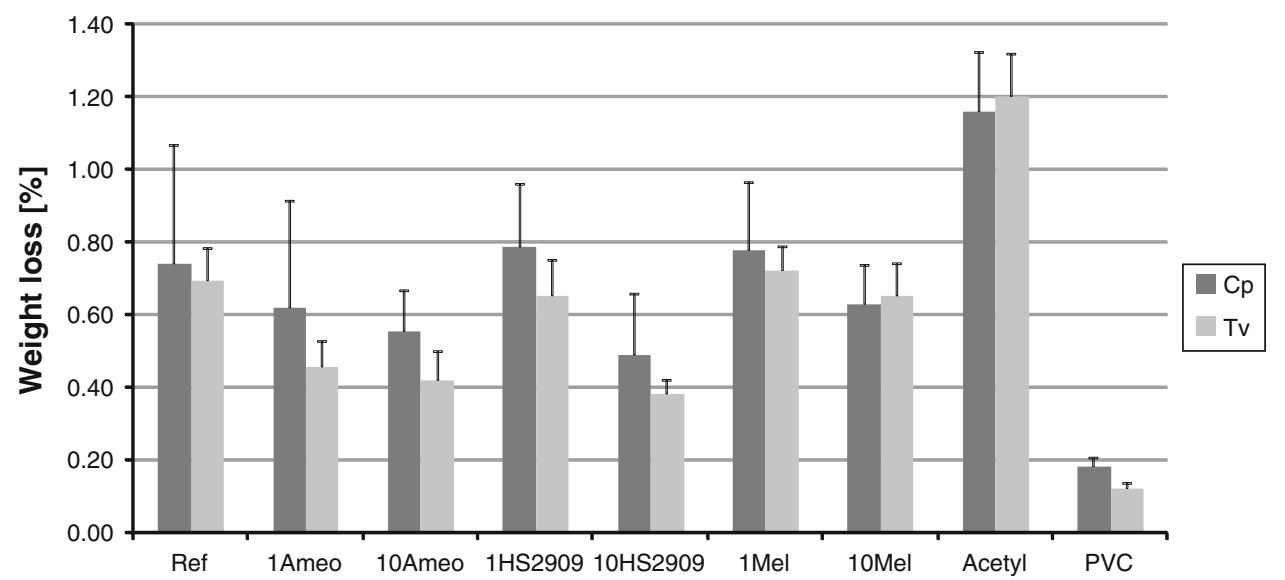

considered. In contrast to PP and PE based WPC, the wood content in PVC based composites is limited up to 50-60 wt \%, due to the higher melt viscosity of the polymer. Several studies showed that the weight losses of composites with a mix ratio of 50:50 \% w/w reached weight losses around 1\% (Schirp and Wolcott 2005; Mankowski and Morrell 2000). A better encapsulation of the wood flour is achieved with increasing polymer content (Verhey et al. 2001). In addition it is reported that with decreasing particle size of the wooden component, the encapsulation is more effective (Verhey and Laks 2002). Both, low wood content and small wood particles (approx. $100 \mu \mathrm{m}$ ) were used in this study and could explain the observed results. With regard to the used modifications, only aminosilane treated composites (10HS2909) showed slightly decreased weight loss values compared to the untreated reference. However, composites that were treated with acetic acid showed slightly increased weight loss values compared to the untreated reference. Furthermore there were no obvious differences in weight losses between brown and white rot fungi. In contrast the size control samples of Picea abies showed higher weight loss values by brown decay than by white rot decay. This observation was not confirmed by the composites, which is a further indication for an unsuitable test design.

\section{Conclusion}

Treated (two different aminosilanes, melamine-formaldehyde resin and acetic anhydride) and untreated PVC/wood flour composites were used to investigate its resistance to brown and white rot fungi. In conclusion, the observed formulations showed high resistance to basidiomycetes according to the used standard. On the one hand this can be explained with the strongly reduced moisture absorption behavior of WPC containing $50 \%$ wood content. Compared to solid wood or wood composites such as particleboard or fiberboard, the wooden component is well encapsulated by the thermoplastic polymer, which leads to lower moisture contents and weight losses during fungal infestation. On the other hand, it was not possible to determine the weight loss of the composites under optimized fungal decay conditions. An adapted pre-treatment is necessary to achieve adequate moisture content of the composite in order to increase the possibility of fungal attack. Hot water pre-treatment (at approx. $60^{\circ} \mathrm{C}$ ) could be a suitable compromise between cool water storage and water boiling test in order to achieve an adequate moisture content without disrupting the composite. Still, there is no unified standard that contains all necessary parameters to measure the resistance of WPC against basidiomycetes, whereas there are ongoing efforts (CEN/TS 15534-1).

Open Access This article is distributed under the terms of the Creative Commons Attribution License which permits any use, distribution, and reproduction in any medium, provided the original author(s) and the source are credited.

\section{References}

Beckers EPJ, Militz H, Stevens M (1994) Resistance of acetylated wood to basidiomycetes, soft rot and blue stain. In: International research group on wood preservation, 94-05-29/06-03, Nusa Dua, Bali, Indonesia 1994. IRG Secretary Stockholm, Sweden, p 11

Brelid PL, Simonson R, Bergman O, Nilsson T (2000) Resistance of acetylated wood to biological degradation. Holz Roh Werkst 58(5):331-337

Chen HC, Chen TY, Hsu CH (2006) Effects of wood particle size and mixing ratios of HDPE on the properties of the composites. Holz Roh Werkst 64(3):172-177

Clemons C (2002) Wood Plastic Composites in the United StatesThe Interfacing of two Industries. Forest Prod J 52(6):10-18

Clemons CM, Ibach RE (2004) Effects of processing method and moisture history on laboratory fungal resistance of wood-HDPE composites. Forest Prod J 54(4):50-57

Dawson-Andoh B, Matuana LM, Harrison J (2004) Mold susceptibility of rigid PVC/wood-flour composites. J Vinyl Add Tech 10(4):179-186

Defoirdt N, Gardin S, Van den Bulcke J, Van Acker J (2010) Moisture dynamics of WPC and the impact on fungal testing. Int Biodeterior Biodegradation 64(1):65-72 
Donath S (2004) Treatment of wood with silanes. Georg-August Universität, Göttingen

Fabiyi JSFJS, McDonald AG, Morrell JJ, Freitag C (2011) Effects of wood species on durability and chemical changes of fungal decayed wood plastic composites. Compos Part a-Applied Sci Manuf 42(5):501-510

Gindl W, Zargar-Yaghubi F, Wimmer R (2003) Impregnation of softwood cell walls with melamine-formaldehyde resin. Bioresour Technol 87(3):325-330

Inoue M, Ogata S, Nishikawa M, Otsuka Y, Kawai S, Norimoto M (1993) Dimensional stability, mechanical-properties, and color changes of a low-molecular-weight melamine-formaldehyde resin impregnated wood. Mokuzai Gakkaishi 39(2):181-189

Jiang HH, Kamdem DP (2004) Development of poly(vinyl chloride)/ wood composites. A literature review. J Vinyl Add Tech 10(2):59-69

Kaczmarek H, Bajer K (2007) Biodegradation of plasticized poly(vinyl chloride) containing cellulose. J Polym Sci Part B-Polym Phys 45(8):903-919

Kim JW, Harper DP, Taylor AM (2008) Effect of wood species on water sorption and durability of Wood-Plastic Composites. Wood Fiber Sci 40(4):519-531

Kim JW, Harper DP, Taylor AM (2009) Effect of extractives on water sorption and durability of wood-plastic composites. Wood Fiber Sci 41(3):279-290

Kokta BV, Maldas D, Daneault C, Beland P (1990a) Composites of Polyvinyl Chloride-Wood Fibers. I. Effect of Isocyanate as a Bonding Agent. Polym-Plast Technol Eng 29(1):87-118

Kokta BV, Maldas D, Daneault C, Béland P (1990b) Composites of polyvinyl chloride-wood fibers. III: effect of silane as coupling agent. J Vinyl Technol 12(3):146-153

Lopez JL, Cooper PA, Sain M (2005) Evaluation of proposed test methods to determine decay resistance of natural fiber plastic composites. Forest Prod J 55(12):95-99

Lukowsky D (1999) Holzschutz mit Melaminharzen. Universität Hamburg, Hamburg

Mankowski M, Morrell JJ (2000) Patterns of fungal attack in woodplastic composites following exposure in a soil block test. Wood Fiber Sci 32(3):340-345

Matuana LM, Balatinecz JJ, Park CB (1998a) Effect of surface properties on the adhesion between PVC and wood veneer laminates. Polym Eng Sci 38(5):765-773

Matuana LM, Woodhams RT, Balatinecz JJ, Park CB (1998b) Influence of interfacial interactions on the properties of PVC cellulosic fiber composites. Polym Compos 19(4):446-455

Müller M, Radovanovic I, Grüneberg T, Militz H, Krause A (2012) Influence of various wood modifications on the properties of polyvinyl chloride/wood flour composites. J Appl Polym Sci 125(1):308-312

Rapp AO, Peek R-D (1996) Melamine resins as preservatives results of biological testing. In: International Research Group on Wood Preservation, Guadeloupe, France, 96-05-19/24 1996. IRG Secretary Stockholm, Sweden, p 4
Rapp AO, Bestgen H, Adam W, Peek RD (1999) Electron energy loss spectroscopy (EELS) for quantification of cell-wall penetration of a melamine resin. Holzforschung 53(2):111-117

Reinprecht L, Novotna H, Stefka V (2007) Density profiles of spruce wood changed by brown-rot and white-rot fungi. Wood Res 52(4): $17-28$

Rowell RM (2007) Challenges in biomass-thermoplastic composites. J Polym Environ 15(4):229-235

Rowell RM, Imamura Y, Kawai S, Norimoto M (1989) Dimensional stability, decay resistance, and mechanical-properties of veneerfaced low-density particleboards made from acetylated wood. Wood Fiber Sci 21(1):67-79

Schirp A, Wolcott MP (2005) Influence of fungal decay and moisture absorption on mechanical properties of extruded wood-plastic composites. Wood Fiber Sci 37(4):643-652

Schirp A, Ibach Rebecca E, Pendleton David E, Wolcott Michael P (2008) Biological degradation of wood-plastic composites (WPC) and strategies for improving the resistance of WPC against biological decay. In: Development of commercial wood preservatives. ACS Symposium Series, vol 982. American Chemical Society, pp 480-507

Silva A, Gartner BL, Morrell JJ (2007) Towards the development of accelerated methods for assessing the durability of wood plastic composites. J Test Eval 35(2):203-210

Sombatsompop N, Chaochanchaikul K (2005) Average mixing torque, tensile and impact properties, and thermal stability of poly(vinyl chloride)/sawdust composites with different silane coupling agents. J Appl Polym Sci 96(1):213-221

Steckel V, Clemons CM, Thoemen H (2007) Effects of material parameters on the diffusion and sorption properties of wood-flour/ polypropylene composites. J Appl Polym Sci 103(2):752-763

Stokke DD, Gardner DJ (2003) Fundamental aspects of wood as a component of thermoplastic composites. J Vinyl Add Tech 9(2):96-104

Takahashi M, Imamura Y, Tanahashi M (1989) Effect of acetylation on decay resistance of wood against brown-rot, white-rot and soft-rot fungi. In: International research group on wood preservation, Lappeenranta, Finland, 89-05-22/26 1989. IRG Secretary Stockholm, Sweden, p 16

Verhey SA, Laks PE (2002) Wood particle size affects the decay resistance of woodfiber/thermoplastic composites. Forest Prod J 52(11-12):78-81

Verhey S, Laks P, Richter D (2001) Laboratory decay resistance of woodfiber/thermoplastic composites. Forest Prod J 51(9):44-49

Vogt D, Karus M, Ortmann S, Schmidt C, Gahle C (2005) Studie Wood-Plastic Composites (WPC)-Holz-Kunststoff-Verbundwerkstoffe-Märkte in Nordamerika, Japan und Europa mit Schwerpunkt auf Deutschland-Technische EigenschaftenAnwendungsgebiete-Preise-Märkte-Akteure. Nova-Institut $\mathrm{GmbH}$, Hürth

Wolcott MP, Englund KA (1999) Technology review of wood-plastic composites. In: 33rd International particleboard/composite materials symposium 1999:103-111 